\title{
PENGARUH IMPLEMENTASI PEMBELAJARAN KOOPERATIF TIPE JIGSAW TERHADAP KEMAMPUAN BERPIKIR KRITIS MATEMATIS SISWA SEKOLAH DASAR
}

\author{
Hani Handayani \\ PGSD STKIP Sebelas April Sumedang \\ hanihandayanipasca@gmail.com
}

\begin{abstract}
The background of the problem in this study originated from students' mathematical critical thinking skills that are still low. One way to overcome these problems is to use Jigsaw cooperative learning. This study aims to determine the effect of the use of jigsaw cooperative learning on the ability to think critically mathematically elementary school students. The method used in this study is a quasi-experimental method with nonequivalent groups pretest-posttets design. The subject of this research is the fifth grade students of SD Negeri Andir Kidul 1, Bandung Municipality. The instrument used was a test item to measure students' mathematical critical thinking skills. Based on the results of data analysis using the $t$ test at a significance level of 0.05 , from the $t$ test results obtained 0.192 results. So it can be concluded that Jigsaw cooperative learning has a significant influence on students' mathematical critical thinking skills.
\end{abstract}

Keywords: critical thingking, cooperative learning, Jigsaw

\section{ABSTRAK}

Latar belakang masalah dalam penelitian ini berawal dari kemampuan berpikir kritis matematis siswa yang masih rendah. Salah satu cara untuk mengatasi permasalahan tersebut yaitu menggunakan pembelajaran kooperatif tipe Jigsaw. Penelitian ini bertujuan untuk mengetahui adanya pengaruh penggunaan pembelajaran kooperatif tipe jigsaw terhadap kemampuan berpikir kritis matematis siswa sekolah dasar. Metode yang digunakan dalam penelitian ini adalah metode quasi eksperimen dengan desain nonequivalent groups pretest-posttets design Subjek pada penelitian ini adalan siswa kelas V SD Negeri Andir Kidul 1 Kotamadya Bandung. Instrumen yang digunakan adalah soal tes untuk mengukur kemampuan berpikir kritis matematis siswa. Berdasarkan hasil analisis data dengan menggunakan uji t pada taraf signifikansi 0,05, dari hasil uji t didapatkan hasil 0.192 sehingga dapat disimpulkan pembelajaran kooperatif tipe Jigsaw memperikan mengaruh yang signifikan terhadap kemampuan berpikir kritis matematis siswa.

Kata Kunci : Berpikir kritis pembelajaran kooperatif, Jigsaw 


\section{A. Pendahuluan}

Kemampuan berpikir kritis merupakan salah satu kemampuan yang penting untuk dikembangkan di sekolah dasar. Menurut Ennis (Lambertus, 2009: 137) berpikir kritis adalah berpikir rasional dan reflektif yang difokuskan pada apa yang diyakini dan dikerjakan. Rasional berarti memiliki keyakinan dan pandangan yang didukung oleh bukti standar, aktual, cukup, dan relevan. Sedangkan berpikir reflektif adalah mempertimbangkan secara aktif, tekun dan hati-hati segala alternatif sebelum mengambil keputusan. Apabila kemampuan berpikir kritis sudah berkembang di diri siswa maka siswa akan terbiasa untuk menyambil kesimpulan yang tepat serta dalam menyelesaikan permasalahan siswa dan akan mampu mengambil langkah penyelasaian secara rasional yang didukung oleh fakta. Hal ini sesuai dengan disampaikan oleh Allegretti dan Frederick (Horenstein dan Niu, 2011: 1) menyatakan bahwa melalui kegiatan berpikir kritis, maka akan membantu siswa untuk mengevaluasi argumen dirinya sendiri dan argumentorang lain, serta siswa dapat menyelesaikan masalah yang kompleks dengan baik dan beralasan.
Sejalan dengan pendapat tersebut Lambertus (2009: 136) menjelasakan bahwa, apabila siswa diberi kesempatan untuk mengunakan pemikirannya dalam tingkatan yang lebih tinggi di setiap tingkat kelas, maka mereka akan terbiasa membedakan antara kebenaran dan ketidak benaran,, penampilan dan kenyatan, fakta dan opini, pengetahuan dan keyakinan.

Kenyataannya kemampuan berpikir kritis matematika kurang dikembangkan dalam pembelajaran sehingga mengakibatkan rendahnya kemampuan berpikir kritis siswa. Rendahnya kemampuan tersebut dapat dilihat dari hasil laporan The Trends in International Mathematics and Science Study (TIMSS) tahun 2007 yang menunjukan bahwa Indonesia berada pada peringkat 36 dari 48 negara. Hasil TIMSS mengungkapkan bahwa kemampuan matematis siswa Indonesia dalam mengerjakan soal-soal tidak rutin sangat lemah, sedangkan untuk mengerjakan soal-soal tidak rutin berkaitan dengan kemampuan berpikir kritis matematika karena dalam menyelesaikan masalah tidak rutin siswa dituntut untuk memiliki kemampuan berpikir yang tinggi. 
Pendas : Jurnal IImiah Pendidikan Dasar, ISSN Cetak : 2477-2143 ISSN Online : 2548-6950

Volume V Nomor 01, Juni 2020

Selain itu menurut hasil Tim Survey IMSTEP-JICA di kota Bandung (Fachrurazi, 2011: 78) menemukan sejumlah kegiatan yang dianggap sulit oleh siswa untuk mempelajarinya dan oleh guru untuk mengajarkannya antara lain, pembuktian pemecahan masalah yang memerlukan penalaran matematis, menemukan, generalisasi atau konjektur, dan menemukan hubungan antara data-data atau fakta yang diberikan. Semua kegiatan tersebut jelas merupakan kegiatan yang menuntut kemampuan berpikir kritis matematika. Dengan demikian dapat disimpulkan bahwa hasil survei menunjukan bahwa siswa mengalami kesulitan jika dihadapkan kepada persoalan yang bersifat tidak rutin yang memerlukan kemampuan berpikir kritis matematika.

Pengembangkan kemampuan berpikir kritis matematika siswa, dapat dilakukan dengan menggunakan desain pembelajaran matematika yang dapat memfasilitasi kemampuan siswa. Upaya untuk meningkatkan kemampuan berpikir kritis dalam pembelajaran dengan cara siswa dilibatkan dalam pembelajaran berbasis masalah yang sesuai dengan kehidupan sehari-hari siswa. Selain itu dalam pembelajaran siswa perlu diberi kesempatan untuk mengkonstruk pengetahuannya secara sendiri, memunculkan ide-idenya, siswa juga difasilitasi dalam kegiatan diskusi karena melalui kegiatan diskusi siswa akan saling bertukar pendapat. Dalam kegiatan diskusi siswa akan belajar untuk menerima dan menolak argumen orang lain yang disertai alasan-alasan yang rasional. Kegiatan ini akan membantu berkembangnya kemampuan berpikir kritis siswa.

Berdasarkan hasil observasi di lapangan selain memiliki manfaat yang positif, kegiatan diskusi dalam pembelajaran terkadang berdampak negatif. Bagi siswa yang tidak terbiasa dengan kegiatan diskusi dan berkerjasama akan membuat suasana pembelajaran menjadi kurang kondusif. Apalagi apabila siswa diberi persoalan dan harus diselesaikan secara kelompok atau berdiskusi, biasanya hanya siswa-siswa tertentu atau siswa-siswa yang pintar saja yang menyelesaikan persoalan tersebut sedangkan anggota kelompok yang lainnya tidak ikut berpartisipasi. Oleh karena itu guru perlu memiliki keterampilan dalam mengondisikan kelas dalam kegiatan diskusi serta guru perlu memilih 
Pendas : Jurnal IImiah Pendidikan Dasar, ISSN Cetak : 2477-2143 ISSN Online : 2548-6950 Volume V Nomor 01, Juni 2020

desain pembelajaran kelompok yang efektif dalam pembelajaran sehingga semua siswa ikut berpartisipasi aktif dalam pembelajaran dan tujuan pembelajaran dapat tercapai khususnya dalam hal ini kemampuan pemecahan masalah dan berpikir kritis matematika seluruh siswa dapat dikembangkan dan ditingkatkan.

Desain pembelajaran yang dapat memfasilitasi seluruh siswa agar dapat berpartisipasi dalam kegiatan diskusi yaitu kooperatife tipe jigsaw. Model kooperatif tipe Jigsaw diduga dapat meningkatkan kemampuan pemecahan masalah dan berpikir kritis matematika setiap siswa karena dalam kegiatan diskusi siswa dikelompokan dalam tim ahli dan tim asal untuk memecahkan masalah matematika. Siswa dituntut untuk memahami dan menyelesaikan permasalahan yang berbeda-beda dalam kelompok asal. Kemudian siswa berdiskusi untuk memecahkan permasalahan dengan kelompok ahli, dimana anggota semua kelompok ahli memiliki tugas yang sama. Setelah masalah diselesaikan, semua anggota kelompok ahli kembali ke kelompok asalnya untuk menyampaikan hal yang telah didiskusikannya di kelompok ahli. Melihat alur kegiatan diskusi dalam kooperatife tipe Jisaw semua anggota kelompok memiliki tanggungjawab dalam menyelesaikan masalah. Melihat dari komponen dalam kegiatan cooperative learning tipe jigsaw diharapkan dapat memfasilitasi siswa dalam meningkatkan kemampuan berpikir kritis matematika siswa.

Cooperative learning adalah model pembelajaran yang mencakupi suatu kelompok kecil siswa yang berkerjasama dalam tim untuk menyelesaikan sebuah masalah, menyelesaikan suatu tugas, atau mengerjakan sesuatu untuk mencapai tujuan bersama lainnya (Suherman, 2001: 218). Sama halnya dengan pendapat yang dikemukakan oleh Johnson \& Johnson (Isjoni, 2009: 45) bahwa cooperative learning adalah mengerjakan sesuatu bersama-sama dengan saling membantu satu sama lainnya sebagai satu tim untuk mencapai tujuan bersama.

Lie (2007: 29) menjelaskan bahwa terdapat unsur-unsur dasar pembelajaran cooperative learning yang membedakannya dengan pembagian kelompok yang dilakukan asal-asalan. Unsur-unsur model pembelajaran cooperative tersebut (Roger dan David Johson dalam Lie, 
2009: 31) yaitu: saling ketergantungan yang positif, tanggungjawab perseorangan, tatap muka, komunikasi antaranggota, dan evaluasi proses kelompok.

Terdapat berbagai macam tipe dalam model kooperatif. Salah satunya yaitu model kooperatif tipe Jigsaw. Model kooperatif tipe Jigsaw dikembangkan oleh Aronson. Dalam tipe Jigsaw guru perlu memperhatikan pengetahuan yang telah dimiliki oleh siswa yang diperolehnya melalui pengalamannya dan membantu siswa untuk mengaitkan pengetahuan dengan kehidupan nyata agar pembelajaran lebih bermakna. Terdapat beberapa tahap dalam model kooperatif tipe Jigsaw (Isjoni, 2009: 57) yaitu: tahap pertama siswa dikelompokan dalam bentuk kelompok-kelompok kecil yang terdiri dari 4-6 orang. Untuk mengoptimalkan manfaat pembelajaran kooperatif, anggota kelompok disusun secara heterogen, baik dari segi kemampuan ataupun dari karakteristik lainnya. Kelompok yang telah disusun dinami tim "asal".

Tahap kedua materi pembelajaran dibagian kepada setiap kelompok menurut anggota tim. Tiaptiap tim diberikan satu set materi/tugas yang lengkap dan masing-masing individu ditugaskan untuk memilih topik masing-masing sesuai dengan materi yang telah ditentukan. Tahap tiga, siswa dipisahkan menjadi kelompok/ tim "ahli" yang terdiri dari seluruh siswa yang memunyai topik/tugas yang sama. Di tim ahli, siswa saling membantu mempelajari materi atau menyelesaikan tugas untuk diinformasikan kepada tim asal. Tahap keempat setelah siswa mempelajari materi/menyelesaikan tugas di tim ahli, kemudian siswa kembali kepada ke tim asli untuk menginformasikan materi tersebut kepada tim asal.

Model kooperatif tipe Jigsaw efektif digunakan di dalam pembelajaran karena melihat tahaptahap dari tipe Jigsaw memungkinkan seluruh siswa dapat aktif dalam kegiatan diskusi karena setiap individu memiliki tanggungjawab untuk menyelesaikan tugasnya masingmasing dan harus diinformasikan kepada teman sekelompoknya. Pembelajaran kooperattif tipe Jigsaw diharapkan dapat meningkatkan kemampuan berpikir kritis siswa sekolah dasar. Salah satu fungsi mempelajari matematika di sekolah dasar adalah agar kemampuan 
Pendas : Jurnal IImiah Pendidikan Dasar, ISSN Cetak : 2477-2143 ISSN Online : 2548-6950

Volume V Nomor 01, Juni 2020

berpikir siswa berkembang secara optimal, dan melalui kemampuankemampuan berpikir tersebut siswa dapat mengaplikasikannya dalam kehidupan sehari-hari.

Salah satu kemampuan berpikir yang dikembangkan dalam matematika adalah kemampuan berpikir kritis. Sebagaimana menurut pendapat seorang psikolog Glaser (Horenstein dan Niu, 2011:2) mendefinisikan berpikir kritis sebagai sikap dan penerapan logis dari keterampilan dalam pemecahan masalah dalam kehidupan sehari-hari.

Chaffee ( Lambertus, 2009: 137) mengemukakan berpikir kritis adala berpikir untuk menyelidiki secara sistematis proses berpikir itu sendiri. Pendapat Chaffee lebih menekankan bahwa proses berpikir kritis adalah proses menganalisis pikirannya sendiri dengan sebaik-baiknya sehingga dapat mengambil keputusan yang tepat. Ennis (Lai, 2011:6) mendefinisikan bahwa berpikir kritis adalah pemikiran yang reflektif dan masuk akal yang difokuskan pada apa yang diyakini untuk mengambil suatu keputusan. Hal ini sesuai dengan pendapat Sunaryo (Inggriyani dan Fajriyah, 2018: 31) Ciri yang dari berpikir kritis adalah murid dapat mengambil solusi dan sikap terhadap suatu masalah dengan baik. Murid tersebut makan berargumen, menilai dan mengevaluasi. Selain itu, Pemahaman berpikir kritis merupakan berpikir reflektif yang berfokus pada memutuskan apa yang harus dipercaya dan dila kukan. Bila murid berpikir kritis, maka murid tersebut tidak akan langsung percaya terhadap suatu berita bohong atau tidak jelas sumbernya.

Berdasarkan teori-teori di atas, dapat diambil kesimpulan bahwa berpikir kritis adalah suatu proses berpikir dalam mengambil suatu keputusan sesuai dengan keyakinan yang dapat dibuktikan kebenarannya sesuai dengan menggunakan berbagai strategi. Melalui kegiatan berpikir kritis siswa dapat menganalisa pikirannya sendiri dan orang lain sehingga siswa dapat mengambil keputusan yang tepat atau menyelesaikan masalah dengan langkah yang rasional. Menurut Ennis (Ardiyanti dan Winartii, 2013: 28) menjelaskan dalam kemampuan berpikir kritis melibatkan dua belas indikator yang kemudian dijabarkan kembali menjadi sub Indikator tersebut 
Pendas : Jurnal IImiah Pendidikan Dasar, ISSN Cetak : 2477-2143 ISSN Online : 2548-6950

Volume V Nomor 01, Juni 2020

masih dapat diuraikan lagi menjadi sub indikator berpikir kritis diantaranya: 1) merumuskan pertanyaan, 2) memberikan contoh, 3) menjawab pertanyaan 'mengapa', 4) melaporkan hasil observasi, 5) menggeneralisasikan data, tabel dan grafik, 6) memberikan kesimpulan,7) mempertimbangkan alternatif jawaban

\section{B. Metode Penelitian}

Metode yang digunakan dalam penelitian ini adalah metode eksperimen. Desain yang digunakan adalah desain nonequivalent groups pretest-posttets design, yang digambarkan sebagai berikut.

\begin{tabular}{|cccc|}
\hline Kelompok & Pretest & Perlakuan & Postest \\
A & $\mathrm{O}$ & $\mathrm{X}$ & $\mathrm{O}$ \\
$\mathrm{B}$ & $\mathrm{O}$ & & $\mathrm{O}$ \\
\hline
\end{tabular}

\section{Gambar 1. Nonequivalent Groups} Pretest-Posttets Design (Sugiono, 2011: 116)

Populasi dari penelitian ini adalah seluruh siswa Kelas V SDN Andir Kidul I Kotamadya Bandung. Sample penelitian terdiri dari 2 kelas. Kelas $\mathrm{V}$ A sebagai kelompok eksperimen sebanyak 25 siswa dan kelas $\mathrm{V} B$ sebagai kelompok kontrol sebanyak
25 siswa. Data-data penelitian dapat dikumpulkan dengan cara memberikan test tertulis berupa 5 soal esay yang berbasis masalah dan sesuai dengan indikator-indikator kemampuan kemampuan berpikir kritis matematika. Analisis data yang digunakan dibantu oleh SPSS 21, dengan langkah-langkah:

1. Menskor jawaban siswa pretes dan postes

2. Menghitung peningkatan kemampuan berpikir kritis matematis menggunakan rumus gain ternormalisasi

3. Menguji normalisasi data skor pretes, dan postes dengan menggunakan uji normalitas Shapiro-Wilk pada taraf signifikansi 0,05 .

4. Jika data normal, dilanjutkan dengan uji homogenitias data skor pretes, dan postes. Pengujian menggunakan uji homogenitas of Variance (Lavene statistic) dengan taraf signifikansi 0,05

5. Melakukan uji perbedaan dua ratarata. Pengujian yang digunakan dalam penelitian ini adalah uji $\mathrm{t}$ Compare Means (independentSampleT-Test) apabila sebaran data normal dan homogen. Untuk 
Pendas : Jurnal IImiah Pendidikan Dasar, ISSN Cetak : 2477-2143 ISSN Online : 2548-6950

Volume V Nomor 01, Juni 2020

uji dua pihak, kriteria pengujian dengan taraf signifikasi $\alpha=0,05$.

\section{C.Hasil Penelitian dan Pembahasan}

Dari hasil pretes kemampuan berpikir kritis matematis untuk mengetahui data berdistribusi normal atau tidaknya, dilakukan uji normalitas. Hipotesis uji normalitas sebaran data dari skor pretes dan postes kemampuan berpikir kritis matematis pada kelas eksperimen dan kelas kontrol.

$H_{0}$ : data berdistribusi normal

$H_{1}$ : data tidak berdistribusi normal

Kriteria pengujian normalitas jika nilai signifikansi $\geq \alpha=0,05$ maka $H_{0}$ diterima $\mathrm{H}_{1}$ ditolak. Hasil uji normalitas Skor Pretes dan Postes berpikir kritis dapat dilihat Tabel 1 di bawah ini.

Tabel 1. Hasil Uji Normalitas Pretes dan

Postes Kemampuan Berpikir Kritis

Matematis Siswa

\begin{tabular}{cccc}
\hline Jenis & Kelas & $\begin{array}{c}\text { Shapiro- } \\
\text { Wilk }\end{array}$ & Ket \\
\cline { 3 - 4 } & & S & \\
\hline Pretes & Eksperimen & .057 & Normal \\
\cline { 2 - 4 } & Kontrol & .000 & Tidak \\
& & & Normal \\
\hline Poste & Eksperimen & .147 & Normal \\
\cline { 2 - 4 } s & Kontrol & .111 & Normal \\
\hline
\end{tabular}

Berdasarkan tabel 1

menunjukan nilai signifikansi uji
Shapiro-Wilk pada skor pretes maupun postes kemampuan berpikir kritis matematis dikelas eksperimen dan kelas kontrol berdistribusi normal. Hal ini dapat dilihat dari nilai signifiakansi yang lebih besar dari 0,05 .

Pada skor pretes dan postes menunjukan data berdistribusi normal, sehingga dilanjutkan dengan Uji Homogenitas Of Variances (Levene Statistic) dengan menggunakan aplikasi SPSS 21 dengan taraf nilai signifikansi $\alpha=0,05$. Hipotesis yang diajukan yaitu:

$\mathrm{H}_{0}$ : varians skor kelas eksperimen dan kelas kontrol homogen.

$\mathrm{H}_{1}$ : varians skor kelas eksperimen dan kelas kontrol tidak homogen.

Untuk keriteria pengujian jika Sig. Based on Mean <0,05 maka $H_{0}$ ditolak dan $H_{1}$ diterima. Perhitungan uji homegenitas telah disajikan dalam tabel 2 dibawah ini. 
Pendas : Jurnal IImiah Pendidikan Dasar, ISSN Cetak : 2477-2143 ISSN Online : 2548-6950

Volume V Nomor 01, Juni 2020

Tabel 2. Hasil Uji Homogenitas Pretes dan Postes Kelas Eksperimen dan Kelas Kontrol Kemampuan Berpikir Kritis Matematis Siswa

\begin{tabular}{lcc}
\hline \multirow{2}{*}{ Jenis } & Homogenity & Ket \\
\cline { 2 - 2 } & $\mathbf{S}$ & \\
\hline Pretes & .057 & Homogen \\
\hline Postes & .350 & Homogen \\
\hline
\end{tabular}

Berdasarkan data pada tabel 2, pretes dan postes kemampuan berpikir kritis matematis siswa berada pada taraf signifikansi 0,057 dan 0,350 lebih besar dari 0,05 sehingga dapat disimpulkan bahwa variansi skor kelas eksperimen dan kelas kontrol bersifat homogen.

Selanjutnya dilakukan uji perbedaan dua rata-rata kelas pretes dan postes kelas ekperimen dan kelas kontrol kemampuan berpikir kritis matematis siswa. Uji perbedaan ratarata dalam skor pretes dan postes dilakukan untuk membuktikan bahwa tidak adanya perbedaan yang signifikasi antara kelas kelompok eksperimen dan kelas kelompok kontrol. Secara ringkas hasil perhitungan kesamaan rata-rata pretes dan postes kemampuan berpikir kritis matematis dapat dilihat pada Tabel 3 dibawah ini.
Tabel 3. Hasil Uji Perbedaan Dua Rata-

Rata Pretes dan Postes Kelas Eksperimen dan Kelas Kontrol Kemampuan Berpikir

Kritis Matematis Siswa

\begin{tabular}{ccl}
\hline Jenis & $\begin{array}{c}\text { Sig. } \\
(\text { 2.Tailed })\end{array}$ & \multicolumn{1}{c}{ Keterangan } \\
\hline Pretes & .067 & $\begin{array}{l}\text { Rata-rata pretes } \\
\text { kelas eksperimen } \\
\text { dan kontrol sama }\end{array}$ \\
\hline Postes & .190 & $\begin{array}{l}\text { Rata-rata prostes } \\
\text { kelas eksperimen } \\
\end{array}$ \\
& & $\begin{array}{l}\text { lebih baik dari kelas } \\
\text { kontrol. }\end{array}$ \\
& &
\end{tabular}

Berdasarkan tabel 3, dapat dilihat untuk rata-rata pretes kelas kontrol dan kelas eksperimen sama. Ini artinya bahwa kemampuan berpikiris kritis matematis kelas eksperimen dan kelas kontrol tidak ada berbedaan yang signifikan. Sedangkan untuk postes, rata-rata postes kelas eksperimen lebih baik dari kelas kontrol. Ini artinya bahwa kemampuan berpikir kritis matematis kelas eksperimen yang menggunakan pembelajaran kooperatif tipe jigsaw lebih baik dari pada kemampuan berpikir kritis kelas kontrol yang menggunakan pembelajaran direct instruction.

Berdasarkan hasil analisis data dapat disimpulkan bahwa menggunaan pembelajaran kooperatif tipe Jigsaw memperikan mengaruh 
Pendas : Jurnal IImiah Pendidikan Dasar, ISSN Cetak : 2477-2143 ISSN Online : 2548-6950

Volume V Nomor 01, Juni 2020

yang signifikan terhadap kemampuan berpikir kritis matematis siswa. Hal ini dapat dilihat dari rata-rata postes kelas eksperimen yang menggunakan pembelajaran kooperatife tipe Jigsaw lebih baik dari pada kelas kontrol yang menggunakan pembelajaran direct instruction.

Pelaksanaan pembelajaran matematika dengan menggunakan pembelajaran kooperatif tipe jigsaw berjalan lancar. Pembelajaran kooperatif tipe jigsaw dengan masingmasing kelompok terdiri dari 4-5 orang. Pembelajaran kooperatif ini mmapu membuat siswa bekerjasama untuk menyelesaikan persoalan sehingga dapat meningkatkan kemampuannya berfikir kritis matematis. Hal ini sejalan dengan pendapat Hill dan Hill (Rofiq, 2010: 9), Kelebihan pembelajaran kooperatif adalah meningkatkan prestasi siswa, memperdalam pemahaman siswa, menyenangkan siswa, dan mengembangkan sikap positif siswa. Selain itu menurut Yamin dan Anshari (Syarifudin, 2011:222) kelebihan dengan diterapkannya kooperatif tipe Jigsaw, adalah 1.) mengajarkan siswa untuk percaya pada guru dan lebih lagi percaya pada kemampuan sendiri untuk berpikir, mencari informasi dan sumber lain, dan dapat belajar dari siswa lain. 2) mendorong siswa untuk mengungkapkan idenya secara verbal dan membandingkan ide dengan temannya. 3) membantu siswa belajar menghormati siswa yang pintar dan siswa yang lemah dalam menerima perbedaan ini. 4) merupakan strategi efektif bagi siswa untuk mencapai hasil akademik dan social termasuk meningkatkan prestasi, percaya diri, dan hubungan interpersonal positif antara satu siswa dengan lainnya, meningkatkan siswa untuk memiliki keterampilan manajemen waktu dan sikap positif terhadap sekolah. 5). banyak menyediakan kesempatan pada siswa untuk membandingkan jawabannya dan ketepatan dari jawaban tersebut dan 6) Meningkatkan kemampuan berpikir kreatif.

Berdasarkan penjelasan di atas, hal itulah yang merupakan faktor penyebab adanya perbedaan yang signifikan antara kemampuan berpikir kritis matematis siswa yang belajar menggunakan kooperatif tipe jigsaw dengan kemampuan berpikir kritis matematis siswa yang belajar menggunakan pembelajaran direct instruction. Sangat terlihat jelas perbedaannya selama pembelajaran 
siswa yang belajar menggunakan pembelajaran kooperatif tipe jigsaw lebih terasah kemampuan berpikir kritis matematisnya, karena dalam pembelajaranya, siswa diberi kesempatan untuk berpikir sendiri dengan kelompoknya dalam memecahkan permasalahan, siswa lebih aktif dalam mengungapkan idenya dengan teman temanya, dalam hal ini khususnya dalam proses memecahkan masalah, sehingga memperlukan kemampuan berpikir kritis, dan siswa juga diberi kesempatan untuk membandingkan jawabanya dengan jawaban kelompok lain, dalam proses ini siswa bukan hanya saja membandingkan benar atau salahnya, tetapi harus menjelasakan alasanya secara verbal mengapa jawabanya dianggap benar/salah, dan jawaban temanya dianggap benar atau salah, dalam proses ini juga mengasah kemampuan berpikir kritis matematis siswa.

\section{E. Kesimpulan}

Terdapat

pengaruh

pembelajaran kooperatif tipe Jigsaw terhadap kemampuan berpikir kritis matematis siswa sekolah dasar. Hal ini dapat dilihatdari hasil analisis data dengan menggunakan uji t pada taraf signifikansi 0,05, dari hasil uji t didapatkan hasil 0.192 sehingga dapat disimpulkan pembelajaran kooperatif tipe Jigsaw memperikan mengaruh yang signifikan terhadap kemampuan berpikir kritis matematis siswa.

\section{DAFTAR PUSTAKA}

Ardiyanti dan Winarti. (2013). "Pengaruh Model Pembelajaran Berbasis Fenomena Untuk Meningkatkan Keterampilan Berpikir Kritis Siswa Sekolah Dasar". Kaunia. 09 (02). 27-33.

Fachruazi. (2011). "Penerapan Pembelajaran Berbasis Masalah Untuk memingkatkan kemampuan Berpikir Kritis Siswa Sekolah dasar." Jurnal Pendidikan UPI Edisi Khusus. 01. 76-89

Horenstein dan Niu. (2011). "Teaching Critical Thinking Skill In Higher. Education: A Review of The Literature". Journal of College Teaching\& learning. 8 (2). 25-42.

Inggriyani, F., \& Fazriyah, N. (2018). Analisis Kemampuan Berpikir Kritis Siswa Dalam Pembelajaran Menulis Narasi Di Sekolah Dasar. Jurnal Pendidikan Dasar, 9(2), 30-41

Isjoni. (2009). Cooperative Learning Efektivitas Pembelajaran Kelompok. Bandung: Alfabeta

Lai, Emily. (2011). Critical Thingking Literatur Review. Pearson. 
Lambertus. (2009). "Pentingnya Melatih Keterampilan Berpikir Kritis dalam Pembelajaran Matematika di SD". Forum Kependidikan. 28 (02). 136-142.

Lie, Anita. (2007). Cooperative Learning Mempraktikkan Cooperative Learning di RuangRuang Kelas. Jakarta : Grasindo

Sugiono. (2011). Metode Penelitian Pendidikan Kuantitatif, Kualitatif, dan R\&D. Bandung: Alfabeta.

Suherman,et.al. (2001). Strategi Pembelajaran Matematika Kontemporer. Bandung: JICAUniversitas Pendidikan Indonesia.

Supinah. (2008). Pembelajaran matematika SD dengan Pendekatan Kontextual dalam Melaksanakan KTSP. Yogyakarta: Depdiknas.

Suwangsih, E dan Tiurlina. (2006). Model Pembelajaran Matematika. Bandung: UPI PRESS. 